Review Article

\title{
Ethnopharmacology, Phytochemistry, and Pharmacology of Syzygium nervosum
}

\author{
Giang Nam Pham $\mathbb{D}^{1},{ }^{1}$ Tu Thanh Thi Nguyen, ${ }^{2}$ and Hieu Nguyen-Ngoc $\mathbb{D}^{3,4}$ \\ ${ }^{1}$ Division of Biotechnology, Vietnam-Korea Institute of Science and Technology, Hanoi 10000, Vietnam \\ ${ }^{2}$ Faculty of Traditional Medicine, Hanoi Medical University, Hanoi 10000, Vietnam \\ ${ }^{3}$ Faculty of Pharmacy, PHENIKAA University, Hanoi 12116, Vietnam \\ ${ }^{4}$ PHENIKAA Research and Technology Institute (PRATI), A\&A Green Phoenix Group JSC, \\ No. 167 Hoang Ngan, Trung Hoa, Cau Giay, Hanoi 11313, Vietnam
}

Correspondence should be addressed to Hieu Nguyen-Ngoc; hieu.nguyenngoc@phenikaa-uni.edu.vn

Received 17 June 2020; Accepted 20 October 2020; Published 2 November 2020

Academic Editor: Mohammad Faisal

Copyright (C) 2020 Giang Nam Pham et al. This is an open access article distributed under the Creative Commons Attribution License, which permits unrestricted use, distribution, and reproduction in any medium, provided the original work is properly cited.

\begin{abstract}
Syzygium nervosum, which belongs to the Myrtaceae plant family, is widely distributed and cultivated in South East Asian countries. The decoction of $S$. nervosum leaves and flower buds has been consumed regularly as a beverage among the Vietnamese and Chinese communities. In addition, it has also been used in traditional medicine for a variety of purposes, notably for influenza, skin diseases, and digestive conditions. To date, there has been a considerable number of publications on chemical profiling and pharmacological activities of $S$. nervosum crude extract and pure isolated compounds. Our analysis indicated the characteristic chemical scaffolds and potential bioactivities on cancer, diabetes, and inflammatory diseases of this plant. The review aims to summarize up-to-date past study results and suggest future research direction on this species, in order to promote clinical applications of $S$. nervosum.
\end{abstract}

\section{Introduction}

Syzygium nervosum (synonyms: Cleistocalyx nervosum, Cleistocalyx operculatus, and Eugenia operculata; common names: "Voi" in Vietnamese, "Shui weng" in Chinese) is widely distributed in tropical areas of South East Asian countries [1-3]. Hot water brewing of $S$. nervosum leaves or flower buds has been commonly consumed as a beverage in Vietnam and China, and it is well known for treating influenza and some digestive conditions according to traditional medicine [1-5]. Besides that, S. nervosum leaves and flower buds were also used externally for inflammatory conditions, including bruises, acnes, and skin ulcers $[2,5,6]$.

In the period of 2002-2019, phytochemical studies have identified a total of 86 natural compounds from leaves and flower buds of $S$. nervosum. The main components of S. nervosum were determined as oleanane-and ursane-type triterpenoids [7], C-methylated flavonoids [8], and polycyclic phloroglucinols $[9,10]$. Of these, C-methylated chalcones were considered as major and pharmacologically responsible constituents of this medicinal plant. S. nervosum crude extract and its major constituent, $2^{\prime}, 4^{\prime}$-dihydroxy- $6^{\prime}$ methoxy-3', $5^{\prime}$-dimethylchalcone (or DMC), were also examined in a variety of pharmacological assays. To a certain extent, some pharmacological effects explained the medicinal uses of this plant in folklore medicine, such as antiviral $[8,11]$, anti-inflammatory [12], and antioxidant activities $[13,14]$. Furthermore, other interesting bioactivities were also discovered, such as anticancer [15-19] and antidiabetic $[20,21]$ properties, which greatly contributed to the potential clinical application of this plant.

In this paper, a comprehensive review related to ethnopharmacology, chemical constituents, and pharmacological studies of $S$. nervosum and its isolated compounds was presented. The authors expect that this review could provide an overview of the current status of $S$. nervosum 
research and a constructive perspective for upcoming studies, in order to encourage the development of clinical therapeutics using this plant in the near future.

\section{Ethnobotany and Ethnopharmacology}

S. nervosum is a branched tree that can be up to $15 \mathrm{~m}$ high with thick brown-to-black bark. The leaf has an elliptic shape with $8-20 \mathrm{~cm}$ long $\times 5-10 \mathrm{~cm}$ wide. Both leaf surfaces have glandular punctate with many secondary veins. Flower buds are oval with a size of $4-6 \mathrm{~mm}$ long $\times 2-3 \mathrm{~mm}$ wide and have bell-shaped gray calyx. Flowers are pale green when fresh and grayish when dried. Fruits have spherical to broadly ovoid shape with violet to black color when mature. Leaves, young branches, and flower buds have a characteristic pleasant fragrance $[1,3,4]$.

The documentation in traditional Vietnamese medicine has recorded that $S$. nervosum leaves and flower buds were used to treat digestive conditions, abdominal pain, and diarrhea. Besides that, the decoction of flower buds was externally used for the treatment of wounds, itchy sores, and acne while the barks were used for antiseptic effects $[1,3,4]$. In Chinese folk medicine, $S$. nervosum leaves and barks were used externally to treat skin ulcers, scabies, and other skin diseases; when used internally, the leave extraction was for the treatment of diarrhea, pimples, and breast inflammation $[2,6]$. The water extraction of flowers was also used for the treatment of influenza, dysentery, and indigestion [5] while the roots were used for jaundice and abdominal pain [2].

\section{Phytochemistry}

Phytochemical studies on S. nervosum flower buds and leaves resulted in the isolation and identification of a total of 86 compounds, which can be categorized into three main groups, including terpenoids, flavonoids, and phloroglucinols. The structures were elucidated by standard spectroscopic methods (1D and 2D NMR, MS). The absolute configuration of complex structures was determined by signs of cotton effect in circular dichroism spectrum [11], singlecrystal X-ray diffraction $[9,10]$, or quantum chemical calculations $[9,10]$. All compound names and respective references are summarized in Table 1.

3.1. Terpenoids. Isolated terpenoids from $S$. nervosum are mostly oleanane- $(\mathbf{6}-\mathbf{9}, \mathbf{2 6}-\mathbf{3 3})$ and ursane-type $(\mathbf{1}-\mathbf{5}, \mathbf{1 0}-\mathbf{2 0})$ triterpenoids. Oleanane-type triterpenoid is also known as $\beta$-amyrin triterpenoid, which consists of five six-membered rings (A-E) with trans-conformation of $\mathrm{A} / \mathrm{B}, \mathrm{B} / \mathrm{C}$, and $\mathrm{C} / \mathrm{D}$ rings and cis-conformation of $\mathrm{D} / \mathrm{E}$ rings. Ursane-type triterpenoid ( $\alpha$-amyrin type) is nearly identical to oleananetype from a chemical perspective, except for two methyls at C-19 and C-20 (in oleanane-type, both methyls connect to C-20).

Naturally occurring triterpenoids from S. nervosum usually possess a carboxylic group at the C-28 position, along with the additional hydroxy or carboxylic or epoxy at various positions. Noticeably, there have been several compounds, in which an intramolecular ester (lactone) functionality can be observed $(\mathbf{5}, \mathbf{8}, \mathbf{9}$, and 21). Besides that, three lupane-type triterpenoids (23-25) and two unusual megastigmane derivatives (73 and 74) were also isolated and structurally elucidated (Figure 1).

3.2. Flavonoids. C-methylated flavonoid is the characteristic group of the compound in S. nervosum with the dominant occurrence of DMC (38). Unlike common flavonoids, $\mathrm{C}$-methylated derivatives possess one or two methyl groups directly linked with the aromatic ring (34-41, 51-65). Besides that, ubiquitous flavonoids and their glycosides were also identified, such as kaempferol (42), quercetin (43), tamarixetin (44), myricetin derivatives, and their glycosides (45-47) (Figure 2).

3.3. Phloroglucinols. "Phloroglucinol" refers to a group of compounds that are biosynthesized via the condensation of three malonyl-CoAs, followed by the cyclization of 3,5diketoheptanedioate. Naturally occurring phloroglucinols usually possess an acyl functionality along with three hydroxyl groups. The phloroglucinols isolated from S. nervosum possess characteristic structural features, such as C-linked methyl groups in the aromatic ring $(66,68$, and 69), the hybridization of terpene and acylphloroglucinol moieties $(\mathbf{8 0}, \mathbf{8 1}, \mathbf{8 4}$, and 85$)$, and polycyclic phloroglucinol dimers (82 and 83) (Figure 3 ).

\section{Analytical Studies}

There have been several published analytical studies for the quantification of major compounds from S. nervosum. The high-performance liquid chromatography (HPLC) was chosen for its relatively short analytical time, baseline peak separation, and applicability for many compound groups. Phytochemical investigations on $S$. nervosum flower buds revealed that flavonoids and triterpenoids are major bioactive compounds. Ye et al. [28] developed an HPLC method to quantify DMC (38) and ursolic acid (16). The analytical procedure was conducted on a ZORBAX Eclipse XDB- $\mathrm{C}_{18}$ $(5 \mu \mathrm{m}, 4.6 \mathrm{~mm} \times 250 \mathrm{~mm})$, a $\mathrm{C}_{18}$ reverse-phase column, eluting with an isocratic program (methanol (A); $0.2 \%$ aqueous $\left.\mathrm{H}_{3} \mathrm{PO}_{4}(\mathrm{~B}) ; \mathrm{A}: \mathrm{B}=93: 7, \mathrm{v} / \mathrm{v}\right)$, UV wavelength at $220 \mathrm{~nm}$, and analytical time of approximately $10 \mathrm{~min}$. The validated method was then applied to quantify the content of two compounds in three samples collected from different locations. As a result, the contents of DMC (38) and ursolic acid (16) were determined in the range of $0.973-1.201 \mathrm{mg} / \mathrm{g}$ and $2.857-3.549 \mathrm{mg} / \mathrm{g}$ of dried plant materials, respectively [28].

DMC (38) was chosen as the analytical marker of S. nervosum for its high content and potential bioactivity. The quantification method was developed and validated on C18 reverse-phase HPLC column, mobile phase consisting of organic solvent (acetonitrile or methanol) and aqueous solvent (containing phosphoric acid or trifluoroacetic acid), and UV detection set at $\sim 330 \mathrm{~nm}$, which is a maxima UV wavelength of DMC (38). These quantification studies 
TABLe 1: Chemical constituents from S. nervosum.

\begin{tabular}{|c|c|c|c|}
\hline No. & Compounds & Parts & References \\
\hline 1 & Cleistocalyxin & Leaves & {$[22]$} \\
\hline 2 & Cleistocalyxic acid A & Leaves & {$[7]$} \\
\hline 3 & Cleistocalyxic acid B & Leaves & [7] \\
\hline 4 & $3 \beta$-Hydroxytaraxast-20-en-28-oic acid & Leaves & [7] \\
\hline 5 & $3 \beta, 21 \alpha$-Dihydroxytaraxast- $28,20 \beta$-olide & Leaves & [7] \\
\hline 6 & Cleistocalyxic acid C & Leaves & [7] \\
\hline 7 & Cleistocalyxic acid D & Leaves & {$[7]$} \\
\hline 8 & Cleistocalyxolide B & Leaves & [7] \\
\hline 9 & $11 \alpha, 12 \alpha$-Epoxy- $2 \alpha, 3 \beta, 23$-trihydroxyolean-28,13 $\beta$-olide & Leaves & [7] \\
\hline 10 & Cleistocalyxic acid $\mathrm{H}$ & Leaves & [7] \\
\hline 11 & $2 \alpha$-Hydroxymicromeric acid & Leaves & [7] \\
\hline 12 & Actinidic acid & Leaves & [7] \\
\hline 13 & Cleistocalyxic acid I & Leaves & [7] \\
\hline 14 & Cleistocalyxic acid J & Leaves & [7] \\
\hline 15 & Cleistocalyxic acid $\mathrm{K}$ & Leaves & [7] \\
\hline 16 & Ursolic acid & Leaves, buds & {$[7,23]$} \\
\hline 17 & Corosolic acid & Leaves & [7] \\
\hline 18 & Asiatic acid & Leaves & [7] \\
\hline 19 & $2 \alpha, 3 \beta, 11 \alpha, 23$-Tetrahydroxyurs-12-en-28-oic acid & Leaves & [7] \\
\hline 20 & $2 \alpha, 3 \beta$-Dihydroxy-24-nor-urs-4(23),12-dien-28-oic acid & Leaves & [7] \\
\hline 21 & $3 \beta$-Hydroxy-20-oxo-21 $(20 \longrightarrow 19)$-abeo-taraxast- $28,21 \beta$-olide & Leaves & {$[7]$} \\
\hline 22 & $\beta$-Sitosterol & Leaves, buds & {$[22,23]$} \\
\hline 23 & Botulin & Leaves & [22] \\
\hline 24 & Betulinic acid & Leaves & {$[7,22]$} \\
\hline 25 & Alphitolic acid & Leaves & [7] \\
\hline 26 & Oleanolic acid & Leaves, buds & {$[7,22,24]$} \\
\hline 27 & Maslinic acid & Leaves, buds & {$[7,22,24]$} \\
\hline 28 & 3-O-trans-p-Coumaroyl maslinic acid & Buds & [24] \\
\hline 29 & 3-O-cis-p-Coumaroyl maslinic acid & Buds & {$[24]$} \\
\hline 30 & Arjunolic acid & Leaves & {$[7,22]$} \\
\hline 31 & Cleistocalyxic acid E & Leaves & [7] \\
\hline 32 & Cleistocalyxic acid F & Leaves & [7] \\
\hline 33 & Cleistocalyxic acid G & Leaves & [7] \\
\hline 34 & $2^{\prime}, 4^{\prime}$-Dihydroxy-6'-methoxy-3', $5^{\prime}$-dimethylchalcone & $\begin{array}{l}\text { Leaves, buds, } \\
\text { seed }\end{array}$ & {$[22,23,25]$} \\
\hline 35 & $3^{\prime}$-Formyl-4' - $^{\prime}$-dihydroxy-2'-methoxy-5' -methylchalcone & Buds & {$[26]$} \\
\hline 36 & $3^{\prime}$-Formyl- $4^{\prime}, 6^{\prime}, 4$-trihydroxy-2' ${ }^{\prime}$-methoxy-5' ${ }^{\prime}$-methylchalcone & Buds & {$[13]$} \\
\hline 37 & $3^{\prime}$-Formyl-6 $6^{\prime}, 4$-dihydroxy- $2^{\prime}$-methoxy-5'-methylchalcone $4^{\prime}-O$ - $\beta$-D-glucopyranoside & Buds & [13] \\
\hline 38 & $2^{\prime}, 4^{\prime}$-Dihydroxy-6 $6^{\prime}$-methoxy- $3^{\prime}, 5^{\prime}$-dimethylchalcone & Buds, leaves & {$[8,11,24]$} \\
\hline 39 & $2^{\prime}, 4^{\prime}$-Dihydroxy-3'-methyl-6'-methoxychalcone & Buds & [8] \\
\hline 40 & (E)-4,2' $4^{\prime}$-Trihydroxy-6 $6^{\prime}$-methoxy- $3^{\prime}, 5^{\prime}$-dimethylchalcone & Buds & {$[8]$} \\
\hline 41 & $2,2^{\prime}, 4^{\prime}$-Trihydroxy- $6^{\prime}$-methoxy- $3^{\prime}, 5^{\prime}$-dimethylchalcone & Buds & {$[8]$} \\
\hline 42 & Kaempferol & Leaves, buds & {$[22,24,26,27]$} \\
\hline 43 & Quercetin & Leaves, buds & {$[22,24,26,27]$} \\
\hline 44 & Tamarixetin & Buds & {$[26,27]$} \\
\hline 45 & Myricetin-3'-methylether 3-O- $\beta$-D-galactopyranoside & Leaves buds & {$[11,26,27]$} \\
\hline 46 & Myricetin- $3^{\prime}$-methylether & Buds & [26] \\
\hline 47 & Myricetin-3', $5^{\prime}$-dimethylether 3-O- $\beta$-D-galactopyranoside & Leaves, buds & {$[11,27]$} \\
\hline 48 & $5,7,8,4^{\prime}$-Tetrahydroxy- $3^{\prime}, 5^{\prime}$-dimethoxyflavone-3-O- $\beta$-D-galactopyranoside & Buds & [26] \\
\hline 49 & Gossypetin-8,3'-dimethylether-3-O- $\beta$-D-galactoside & Buds & {$[26]$} \\
\hline 50 & Luteolin & Buds & {$[24]$} \\
\hline 51 & 7-Hydroxy-5-methoxy-6,8-dimethylflavone & Buds & {$[8,26]$} \\
\hline 52 & (2S)-8-Formyl-6-methylnaringenin & Buds & {$[13]$} \\
\hline 53 & $(2 S)$-8-Formyl-6-methylnaringenin $7-O-\beta$-D-glucopyranoside & Buds & {$[13]$} \\
\hline 54 & (2S)-8-Formyl-5-hydroxy-7-methoxy-6-methylflavanone & Buds & {$[8,26]$} \\
\hline 55 & 8-Formyl-5,7-dihydroxyl-6-methylflavanone & Buds & {$[26]$} \\
\hline 56 & (2S)-6-Formyl-8-methyl-7-O-methylpinocembrin & Buds & {$[8]$} \\
\hline 57 & (2S)-7,2'-Dihydroxy-5-methoxy-6,8-dimethylflavanone & Leaves & {$[11]$} \\
\hline 58 & (2S)-7-Hydroxy-5-methoxy-6,8-dimethylflavanone & Leaves & {$[11]$} \\
\hline 59 & (2S)-7-Hydroxy-5-methoxy-8-methylflavanone & Buds & {$[8]$} \\
\hline
\end{tabular}


TABle 1: Continued.

\begin{tabular}{|c|c|c|c|}
\hline No. & Compounds & Parts & References \\
\hline 60 & (2S)-8-methylpinocembrin & Buds & {$[8]$} \\
\hline 61 & (2S)-5-Hydroxy-7-methoxy-6,8-dimethylflavanone & Buds & {$[8]$} \\
\hline 62 & (2S)-5,7-Dihydroxy-6,8-dimethylflavanone & Buds & {$[8]$} \\
\hline 63 & (2S)-2,7-Dihydroxy-5-methoxy-6,8-dimethylflavanone & Buds & {$[8]$} \\
\hline 64 & $(2 S, 3 S)$-2,3-trans-5,7-Dihydroxy-6,8-dimethyldihydroflavonol & Buds & {$[8]$} \\
\hline 65 & 7-Hydroxy-5-methoxy-6,8-dimethylisoflavone & Leaves, buds & {$[8,11]$} \\
\hline 66 & Hariganetin & Seed & {$[25]$} \\
\hline 67 & 3-O-Methylellagic acid- $4^{\prime}-O-\alpha$-L-rhamnopyranoside & Leaves & {$[11]$} \\
\hline 68 & (2S)-2,6-Dihydroxy-4-methoxy-5,7-dimethylcoumaran-3-one & Buds, leaves & {$[11,24]$} \\
\hline 69 & $2,4^{\prime}, 6^{\prime}$-Trihydroxy-2'-methoxy-3 $3^{\prime}, 5^{\prime}$-dimethylacetophenone & Leaves & [11] \\
\hline 70 & 1-[(2-Methylbutyryl)-phloroglucinyl $]-\beta$-D-glucopyranoside & Buds & {$[24]$} \\
\hline 71 & (trans)-4-Hydroxy-5-(2-hydroxypropan-2-yl)-2-methylcyclopent-2-en-1-one & Buds & [24] \\
\hline 72 & 4-Hydroxy-2,2,5-trimethylcyclopent-4-ene-1,3-dione & Buds & {$[24]$} \\
\hline 73 & $4^{\prime}$-Dihydrophaseic acid & Buds & [24] \\
\hline 74 & $\begin{array}{c}\text { 5-(3S,8S-Dihydroxy-1R,5S-dimethyl-7-oxa-6-oxobicyclo [1-3]-oct-8-yl)-3-methyl-2Z,4E- } \\
\text { Pentadienoic acid }\end{array}$ & Buds & {$[24]$} \\
\hline 75 & 4-Hydroxybenzoic acid & Buds & {$[24]$} \\
\hline 76 & Methyl 3,4,5-trihydroxybenzoate & Buds & {$[24]$} \\
\hline 77 & 4-Hydroxy-3,5-dimethoxybenzoic acid & Buds & {$[24]$} \\
\hline 78 & 3-Hydroxy-3-phenylpropanoic acid & Buds & {$[24]$} \\
\hline 79 & Cinnamic acid & Buds & {$[24]$} \\
\hline 80 & Cleistocaltone A & Buds & [9] \\
\hline 81 & Cleistocaltone B & Buds & {$[9]$} \\
\hline 82 & Cleistoperlone A & Leaves & {$[10]$} \\
\hline 83 & Cleistoperlone B & Leaves & {$[10]$} \\
\hline 84 & Operculatol A & Leaves & {$[10]$} \\
\hline 85 & Operculatol B & Leaves & {$[10]$} \\
\hline 86 & 1-Tetratriacontanol & Leaves & {$[22]$} \\
\hline
\end{tabular}

revealed the content of DMC in flower buds ranging from $0.75 \%$ to $1.85 \%$ in different extracts $[12,29]$.

Tran et al. [24] quantified the content of maslinic acid (27) and its coumaronyl derivatives (28 and 29), which were potent RANKL-induced osteoclast formation inhibitors, by HPLC. The optimal condition was performed on a Sunfire $\mathrm{C}_{18}$ column $(4.6 \times 150 \mathrm{~mm}, 5 \mu \mathrm{m})$, eluting with gradient of acetonitrile and $0.1 \%$ trifluoroacetic acid in the water, and UV lamp set at $205 \mathrm{~nm}$. The content of compounds 27-29 was determined as $7.20,0.16$, and $0.52 \%$, respectively [24].

Besides that, the total phenolic content of S. nervosum was also quantified to link with pharmacological effects. The common method is using the Folin-Ciocalteu method. In this method, the extract is diluted and shaken with Folin-Ciocalteu reagent (a mixture of phosphomolybdate and phosphotungstate). After that, the absorbance of the mixture was measured by a spectrophotometer at specific UV wavelengths (commonly at $\sim 500$ and $\sim 750 \mathrm{~nm}$ ). Gallic acid and catechin were usually chosen as reference standards, and the total phenolic content was expressed as gallic acid (GAE) or catechin equivalents (CE). The total phenolic content of $S$. nervosum was determined in different plant parts as follows: flower bud (58.5-157.7 mg GAE/g [30, 31]; $122.5 \mathrm{mg} \mathrm{CE} / \mathrm{g}$ [20]), leaves (1.03 mg-511.4 mg GAE/g) $[30,32]$, and berry (5.35-61.1 mg GAE/g) [33, 34].

Noticeably, Zhang and $\mathrm{Lu}$ [31] compared the total polyphenol and DMC (38) content obtained from different extraction solvents $(0,30,60,95 \%$ ethanol, petroleum ether, and ethyl acetate extracts). As a result, the total polyphenol content ranked in the order of "aqueous extract $>30 \%$ ethanol extract $>60 \%$ ethanol extract $>95 \%$ ethanol extract $>$ petroleum ether extract $>$ ethyl acetate extract." The petroleum ether extract contained the highest content of DMC (1.85\%), followed by ethyl acetate extract (1.14\%), 95\% ethanol extract $(0.75 \%), 60 \%$ ethanol extract $(0.59 \%), 30 \%$ ethanol extract $(0.23 \%)$, and aqueous extract (not detected). The authors also pointed out the close relation between pancreatic $\alpha$-amylase inhibitory effects and total polyphenol content; however, the content of DMC (38) was determined to be a decisive factor for inhibitory activity on pancreatic lipase [31].

\section{Synthesis of Bioactive Compounds from S. nervosum and Their Analogues}

Since DMC (38) is an interesting bioactive compound with a wide range of pharmacological effects, the efforts of DMC mass production are necessary for further research and clinical application. Although DMC was determined as the major constituent of $S$. nervosum flower buds, its content was not high enough for industry-scaled extraction and isolation. Mass production of bioactive compounds by microbial fermentation has recently become a new approach to deal with this question of research. Wang et al. [35] published a study on optimizing conditions for biosynthesizing DMC from Ceriporia lacerate DMC11-6, a new endophytic fungus. From an optimal fermentation medium, DMC can be produced in a high amount 

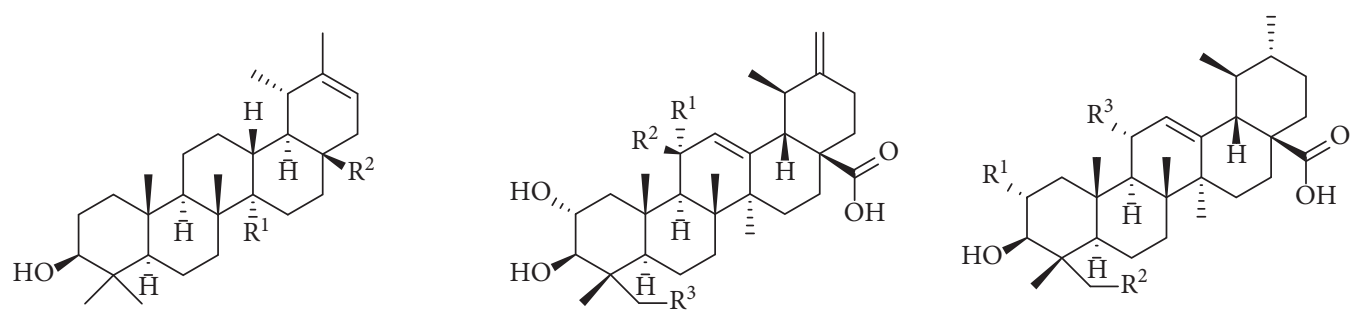

$$
\begin{array}{ll}
1 & \mathrm{R}^{1}=\mathrm{CH}_{3} ; \mathrm{R}^{2}=\mathrm{CHO} \\
2 & \mathrm{R}^{1}=\mathrm{CHO} ; \mathrm{R}^{2}=\mathrm{COOH} \\
3 & \mathrm{R}^{1}=\mathrm{COOH} ; \mathrm{R}^{2}=\mathrm{COOCH} 3 \\
4 & \mathrm{R}^{1}=\mathrm{CH}_{3} ; \mathrm{R}^{2}=\mathrm{COOH}
\end{array}
$$

$$
\begin{array}{ll}
11 & \mathrm{R}^{1}=\mathrm{R}^{2}=\mathrm{R}^{3}=\mathrm{H} \\
12 & \mathrm{R}^{1}=\mathrm{R}^{2}=\mathrm{H} ; \mathrm{R}^{3}=\mathrm{OH} \\
13 & \mathrm{R}^{1}=\mathrm{R}^{3}=\mathrm{OH} ; \mathrm{R}^{2}=\mathrm{H} \\
14 & \mathrm{R}^{1}=\mathrm{OCH}_{3} ; \mathrm{R}^{2}=\mathrm{H} ; \mathrm{R}^{3}=\mathrm{OH} \\
15 & \mathrm{R}^{1}+\mathrm{R}^{2}=\mathrm{O} ; \mathrm{R}^{3}=\mathrm{OH}
\end{array}
$$

$$
\begin{array}{ll}
16 & \mathrm{R}^{1}=\mathrm{R}^{2}=\mathrm{R}^{3}=\mathrm{H} \\
17 & \mathrm{R}^{1}=\mathrm{OH} ; \mathrm{R}^{2}=\mathrm{R}^{3}=\mathrm{H} \\
18 & \mathrm{R}^{1}=\mathrm{R}^{2}=\mathrm{OH} ; \mathrm{R}^{3}=\mathrm{H} \\
19 & \mathrm{R}^{1}=\mathrm{R}^{2}=\mathrm{R}^{3}=\mathrm{OH}
\end{array}
$$

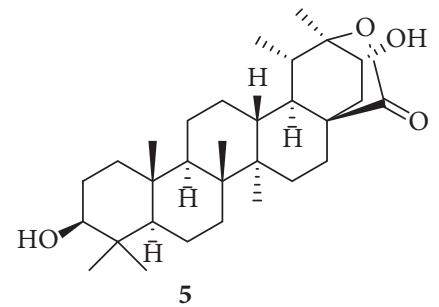

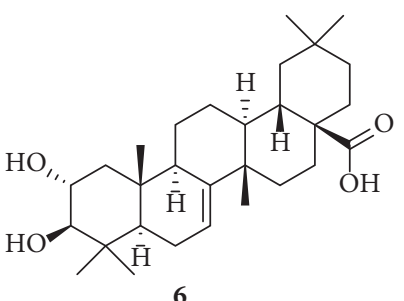

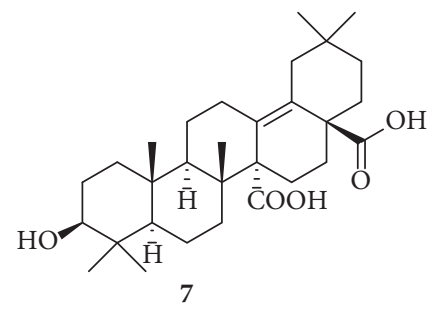

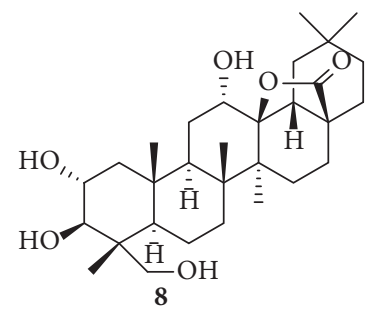

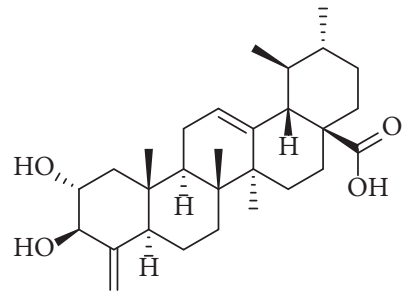

20

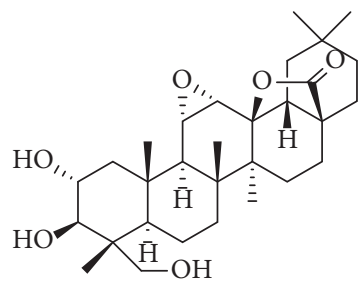

9

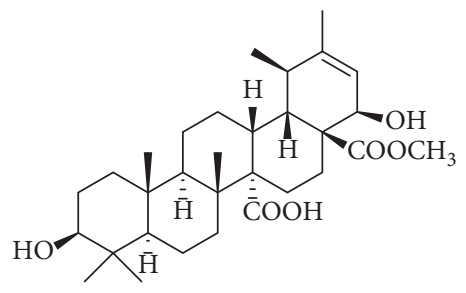

10

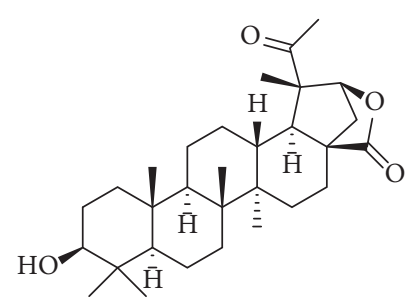

21<smiles>CCC(CC[C@H](C)[C@H]1CC[C@H]2[C@@H]3CC=C4CC(O)CC[C@]4(C)[C@H]3CC[C@@]21C)C(C)C</smiles>

22

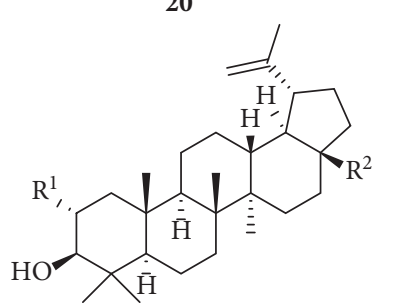

$23 \mathrm{R}^{1}=\mathrm{H} ; \mathrm{R}^{2}=\mathrm{CH}_{2} \mathrm{OH}$

$24 \mathrm{R}^{1}=\mathrm{H} ; \mathrm{R}^{2}=\mathrm{COOH}$

$25 \mathrm{R}^{1}=\mathrm{OH} ; \mathrm{R}^{2}=\mathrm{COOH}$<smiles>O=C(O)/C=C/c1ccc(O)cc1</smiles>

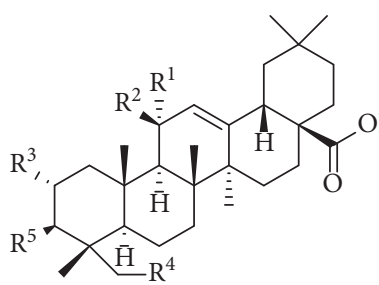

$\begin{array}{lllll}\mathrm{R}^{1} & \mathrm{R}^{2} & \mathrm{R}^{3} & \mathrm{R}^{4} & \mathrm{R}^{5}\end{array}$

$\begin{array}{llllll}26 & \mathrm{H} & \mathrm{H} & \mathrm{H} & \mathrm{H} & \mathrm{OH}\end{array}$

$\begin{array}{llllll}27 & \mathrm{H} & \mathrm{H} & \mathrm{OH} & \mathrm{H} & \mathrm{OH}\end{array}$

$28 \mathrm{H} \quad \mathrm{H} \quad \mathrm{OH} \quad \mathrm{H} \quad$ trans $^{-} p$-Coumaroyl

$29 \mathrm{H} \quad \mathrm{H} \quad \mathrm{OH} \quad \mathrm{H}$ cis ${ }^{-} p$-Coumaroyl

$\begin{array}{llllll}30 & \mathrm{H} & \mathrm{H} & \mathrm{OH} & \mathrm{OH} & \mathrm{OH}\end{array}$

$\begin{array}{llllll}31 & \mathrm{OH} & \mathrm{H} & \mathrm{OH} & \mathrm{OH} & \mathrm{OH}\end{array}$

$32 \mathrm{OCH}_{3} \mathrm{H} \quad \mathrm{OH} \quad \mathrm{OH} \quad \mathrm{OH}$

$33=\mathrm{O} \quad \mathrm{OH} \quad \mathrm{OH} \quad \mathrm{OH}$

Figure 1: Isolated terpenoids from S. nervosum.

$(100.24 \pm 1.60 \mu \mathrm{g} / \mathrm{L})$. The authors also suggested that further investigation using genetic tools to overexpress DMC-biosynthesizing genes is required [35].
Compound 35 was first isolated and structurally elucidated by Ye et al. [36] with moderate anticancer activities. In order to shed light on the structure-activity relationship of 
<smiles>[R]c1ccc(/C=C/C(=O)c2c([R])c([R])c([R])c([R])c2[R])cc1</smiles>

34-37<smiles>[R]c1cc(-c2oc3c([R])c(O)cc(O)c3c(=O)c2[R])cc([R])c1[R]</smiles><smiles>[R]c1ccc([C@@H]2CC(=O)c3c([R])c([R])c([R])c([R])c3O2)c([R])c1</smiles>

$52-62$<smiles>Cc1c(O)c(C)c2c(c1O)C(=O)[C@H](O)[C@H](c1ccccc1)O2</smiles>

64<smiles>CC1=C2O[C@@H](c3ccccc3)CC(O)=C2C(=O)C(C)(C)C1=O</smiles>

66<smiles>[R]c1ccc(/C=C/C(=O)c2c([R])c([R])c(O)c(C)c2[R])c([R])c1</smiles><smiles>COc1c(C)c(O)c(C)c2oc(-c3ccccc3)cc(=O)c12</smiles><smiles>COc1c(C)c(O)c(C)c2c1C(=O)C[C@@](O)(c1ccccc1)O2</smiles>

63<smiles>COc1c(C)c(O)c(C)c2occ(-c3ccccc3)c(=O)c12</smiles>

65

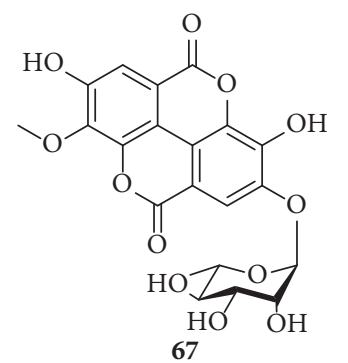

\begin{tabular}{|c|c|c|c|c|c|c|}
\hline & $\mathrm{R}^{1}$ & $\mathrm{R}^{2}$ & $\mathrm{R}^{3}$ & $\mathrm{R}^{4}$ & $\mathrm{R}^{5}$ & $\mathrm{R}^{6}$ \\
\hline 34 & $\mathrm{OH}$ & $\mathrm{CH}_{3}$ & $\mathrm{OH}$ & $\mathrm{CH}_{3}$ & $\mathrm{OCH}_{3}$ & $\mathrm{H}$ \\
\hline 35 & $\mathrm{OCH}_{3}$ & $\mathrm{CHO}$ & $\mathrm{OH}$ & $\mathrm{CH}_{3}$ & $\mathrm{OH}$ & $\mathrm{H}$ \\
\hline & $\mathrm{OCH}_{3}$ & $\mathrm{CHO}$ & $\mathrm{OH}$ & $\mathrm{CH}_{3}$ & $\mathrm{OH}$ & $\mathrm{OH}$ \\
\hline & $\mathrm{OCH}_{3}$ & $\mathrm{CHO}$ & $\beta^{-} \mathrm{D}-\mathrm{glc}$ & $\mathrm{CH}_{3}$ & $\mathrm{OH}$ & \\
\hline 38 & $\mathrm{OCH}_{3}$ & $\mathrm{CH}_{3}$ & $\mathrm{OH}$ & $\mathrm{H}$ & $\mathrm{H}$ & \\
\hline 39 & $\mathrm{OCH}_{3}$ & $\mathrm{H}$ & $\mathrm{OH}$ & $\mathrm{H}$ & $\mathrm{H}$ & \\
\hline 40 & $\mathrm{OH}$ & $\mathrm{CH}_{3}$ & $\mathrm{OCH}_{3}$ & $\mathrm{H}$ & $\mathrm{OH}$ & \\
\hline 41 & $\mathrm{OH}$ & $\mathrm{CH}_{3}$ & $\mathrm{OCH}_{3}$ & $\mathrm{OH}$ & $\mathrm{H}$ & \\
\hline 42 & $\mathrm{H}$ & $\mathrm{OH}$ & $\mathrm{H}$ & $\mathrm{OH}$ & $\mathrm{H}$ & \\
\hline 43 & $\mathrm{H}$ & $\mathrm{OH}$ & $\mathrm{H}$ & $\mathrm{OH}$ & $\mathrm{OH}$ & \\
\hline 44 & $\mathrm{H}$ & $\mathrm{OH}$ & $\mathrm{H}$ & $\mathrm{OCH}_{3}$ & $\mathrm{OH}$ & \\
\hline 45 & $\mathrm{H}$ & $\beta^{-} \mathrm{D}-\mathrm{gal}$ & $\mathrm{OH}$ & $\mathrm{OH}$ & $\mathrm{OCH}_{3}$ & \\
\hline 46 & $\mathrm{H}$ & $\mathrm{OH}$ & $\mathrm{OH}$ & $\mathrm{OH}$ & $\mathrm{OCH}_{3}$ & \\
\hline 47 & $\mathrm{H}$ & $\beta^{-} \mathrm{D}$-gal & $\mathrm{OCH}_{3}$ & $\mathrm{OH}$ & $\mathrm{OCH}_{3}$ & \\
\hline 48 & $\mathrm{OH}$ & $\beta^{-} \mathrm{D}-\mathrm{gal}$ & $\mathrm{OCH}_{3}$ & $\mathrm{OH}$ & $\mathrm{OCH}_{3}$ & \\
\hline 49 & $\mathrm{OCH}_{3}$ & $\beta^{-}$D-gal & $\mathrm{H}$ & $\mathrm{OH}$ & $\mathrm{OCH}_{3}$ & \\
\hline 50 & $\mathrm{H}$ & $\mathrm{H}$ & $\mathrm{H}$ & $\mathrm{OH}$ & $\mathrm{OH}$ & \\
\hline 52 & $\mathrm{CHO}$ & $\mathrm{OH}$ & $\mathrm{CH}_{3}$ & $\mathrm{OH}$ & $\mathrm{H}$ & $\mathrm{OH}$ \\
\hline 53 & $\mathrm{CHO}$ & $\beta^{-} \mathrm{D}-\mathrm{glc}$ & $=\mathrm{CH}_{3}$ & $\mathrm{OH}$ & $\mathrm{H}$ & $\mathrm{OH}$ \\
\hline 54 & $\mathrm{CHO}$ & $\mathrm{OCH}_{3}$ & ${ }_{3} \mathrm{CH}_{3}$ & $\mathrm{OH}$ & $\mathrm{H}$ & $\mathrm{H}$ \\
\hline 55 & $\mathrm{CHO}$ & $\mathrm{OH}$ & $\mathrm{CH}_{3}$ & $\mathrm{OH}$ & $\mathrm{H}$ & $\mathrm{H}$ \\
\hline 56 & $\mathrm{CH}_{3}$ & $\mathrm{OCH}_{3}$ & $3 \mathrm{CHO}$ & $\mathrm{OH}$ & $\mathrm{H}$ & $\mathrm{H}$ \\
\hline 7 & $\mathrm{CH}_{3}$ & $\mathrm{OH}$ & $\mathrm{CH}_{3}$ & $\mathrm{OCH}_{3}$ & ${ }_{3} \mathrm{OH}$ & $\mathrm{H}$ \\
\hline 58 & $\mathrm{CH}_{3}$ & $\mathrm{OH}$ & $\mathrm{CH}_{3}$ & $\mathrm{OCH}_{3}$ & $3 \mathrm{H}$ & $\mathrm{H}$ \\
\hline 9 & $\mathrm{CH}_{3}$ & $\mathrm{OH}$ & $\mathrm{H}$ & $\mathrm{OCH}_{3}$ & $3 \mathrm{H}$ & $\mathrm{H}$ \\
\hline 0 & $\mathrm{CH}_{3}$ & $\mathrm{OH}$ & $\mathrm{H}$ & $\mathrm{OH}$ & $\mathrm{H}$ & $\mathrm{H}$ \\
\hline & $\mathrm{CH}_{3}$ & $\mathrm{OCH}_{3}$ & ${ }_{3} \mathrm{CH}_{3}$ & $\mathrm{OH}$ & $\mathrm{H}$ & $\mathrm{H}$ \\
\hline & $\mathrm{CH}_{3}$ & $\mathrm{OH}$ & $\mathrm{CH}_{3}$ & $\mathrm{OH}$ & $\mathrm{H}$ & \\
\hline
\end{tabular}<smiles>OCC1OC(O)C(O)C(O)C1O</smiles>

$\beta^{-}$D-Glucopyranosyl

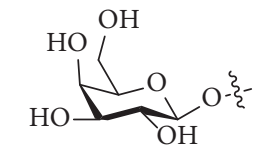

$\beta^{-} \mathrm{D}-$ Galactopyranosyl

Figure 2: Phenolic compounds from S. nervosum.

bioactive chalcones from $S$. nervosum, Zhuo et al. [37] proposed a concise synthesis of $3^{\prime}$-formyl- $4^{\prime}, 6^{\prime}$-dihydroxy$2^{\prime}$-methoxy-5'-methylchalcone (35) and its series of B-ringmodified analogues from 2,4,6-trihydroxyacetophenone. The results showed that the analogue with bromide substitution at C-4 on B-ring exhibited a significant improved antiproliferative activity with $\mathrm{IC}_{50}$ values ranging from $10.8 \pm 0.9$ to $20.2 \pm 1.6 \mu \mathrm{M}$, which was 10 times more potent compared to the lead compound (35) [37]. In another synthetic study, Wang's group dealt with the hydrophobic nature of DMC, which made the compound barely soluble in water, leading to the limited application for future clinical use. The authors synthesized a series of DMC analogues with different ionizable groups, which improved significantly hydrophilic properties of the DMC scaffold, as well as anticancer activities against various types of cancer cells [38].

Although there has been a modest number of synthetic publications on bioactive compounds from S. nervosum, the natural-product-inspired synthetic approach should be taken into consideration for the future development of novel chemical entities for targeted diseases. However, the past studies only focused on C-methylated flavonoids and their analogues but neglected other bioactive compound groups, which are also found from the plant in considerable amounts, for example, triterpenoids and phloroglucinols. Future studies should pay more attention to that area of research.

\section{Pharmacological Activities}

\subsection{Anticancer Activities}

6.1.1. Cytotoxicity against Different Cancer Cell Lines. There have been studies on cytotoxicity of DMC (38), the major chalcone isolated from $S$. nervosum, on different cancer cell lines. The half-maximal inhibitory concentration 
<smiles>COc1c(C)c(O)c(C)c2c1C(=O)C(O)O2</smiles>

68<smiles>CC1=C(O)C(=O)C(C)(C)C1=O</smiles>

72<smiles>O=C(O)/C=C/c1ccccc1</smiles>

79<smiles>CC(C)=CCC/C(=C/CC1(C)C(=O)C(=C(O)/C=C/c2ccccc2)C(=O)C(C)(C)C1=O)CO</smiles>

81<smiles>COc1c(C)c(O)c(C)c(O)c1C(=O)CO</smiles>

69<smiles>CCC(C)C(=O)c1c(O)cc(O)cc1OC(O)C(O)CO</smiles>

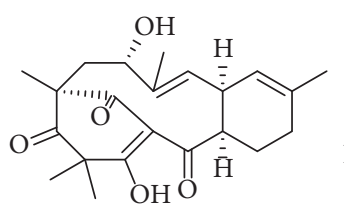

80

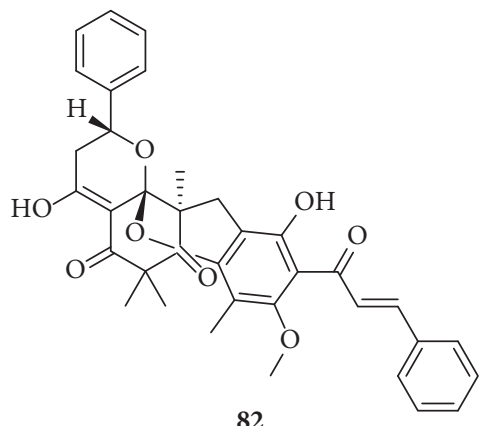

82<smiles>[R]C(=O)c1cc([R])c(O)c([R])c1</smiles>

$75 \mathrm{R}^{1}=\mathrm{R}^{2}=\mathrm{H}$ $76 \mathrm{R}^{1}=\mathrm{CH}_{3} ; \mathrm{R}^{2}=\mathrm{OH}$ $77 \mathrm{R}^{1}=\mathrm{H} ; \mathrm{R}^{2}=\mathrm{OCH}_{3}$<smiles>CC1=CC(O)C(C(C)(C)O)C1=O</smiles>

71<smiles>O=C(O)CC(O)c1ccccc1</smiles>

78

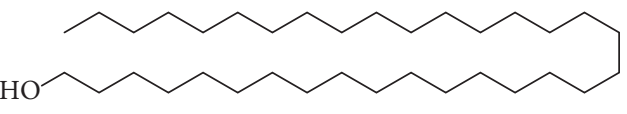

86

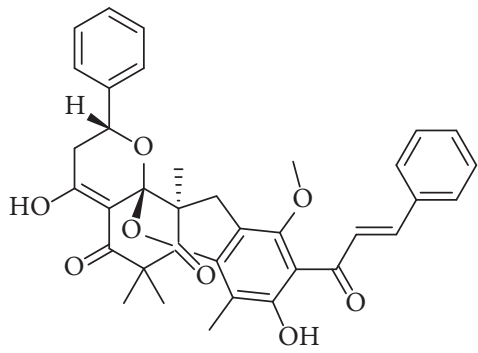

83<smiles>COc1c2c(c(C)c(O)c1C(=O)/C=C/c1ccccc1)O[C@@H]1[C@H]3C[C@@H](C[C@@H]1C2)C3(C)C</smiles>

84<smiles>COc1c(C)c2c(c(O)c1C(=O)/C=C/c1ccccc1)C[C@H]1CC3C[C@@H](C1(C)C)[C@]2(C)O3</smiles>

85

Figure 3: Phloroglucinols and miscellaneous compounds from S. nervosum.

$\left(\mathrm{IC}_{50}\right)$ and respective cancer cell lines are summarized in Table 2.

In general, DMC was found to be active against many cancer cell lines with different magnitude of cytotoxicity. The chalcone exhibited the strongest cytotoxicity against A549 cells with an $\mathrm{IC}_{50}$ value of $2.3 \pm 0.44 \mu \mathrm{M}$. DMC was also very active against a variety of cancer cell lines with $\mathrm{IC}_{50}$ ranging from 8 to $15 \mu \mathrm{M}$, such as HepG2, ASK, P-388, and PANC-1. For other cancer cell lines, DMC only showed moderate activities ( $\left.\mathrm{IC}_{50} 30-85 \mu \mathrm{M}\right)$.

However, there does exist inconsistency among reported data on cytotoxicity of DMC in the same cancer cells from independent pharmacological studies $[25,38]$. The variation in $\mathrm{IC}_{50}$ may be due to the differences in the evaluation methods. Currently, the most common method for cytotoxicity measurement is the MTT assay, which was applied to identify the $\mathrm{IC}_{50}$ of DMC in a study by Wang et al. $[38,40]$.
However, Chailungka et al. used the TCA method, in which treated cells were trypsinized and resettled in the new culture plates before the TCA measurement [25]. Consequently, a more complicated process may result in differences in $\mathrm{IC}_{50}$ identification. Furthermore, the concentration of DMSO is also an issue. Since DMSO was reported to expose cytotoxicity in a dose-dependent manner in certain cell lines [41], therefore, the differences in DMSO concentration used as a negative control in different measurement methods may also cause the variety of $\mathrm{IC}_{50}$ values of DMC in the cytotoxicity assay.

6.1.2. Reversal Effects of DMC (38) and Its Analogues on Drug-Resistant Cancer Cell Lines. Multidrug resistance is one of the major challenges for the chemotherapeutic treatment of cancer. Noticeably, cotreatment of DMC (38) 
TABLE 2: Cytotoxicity $\left(\mathrm{IC}_{50}\right)$ of DMC against different cancer cell lines.

\begin{tabular}{|c|c|c|c|}
\hline Cancer cell line & Description & $\mathrm{IC}_{50}(\mu \mathrm{m})$ & Reference \\
\hline P-388 & Mouse lymphoid neoplasm & 10.31 & {$[25]$} \\
\hline KB & Human epidermoid carcinoma in the mouth & 15.90 & - \\
\hline MCF-7 & Human breast cancer & 14.51 & - \\
\hline A549 & Human lung cancer & 13.04 & - \\
\hline ASK & Rat glioma & 9.00 & - \\
\hline PANC-1 & Human pancreas & $10.5 \pm 0.8$ & {$[39]$} \\
\hline MIA-PACA2 & Human pancreatic carcinoma & $12.2 \pm 0.9$ & - \\
\hline SMMC-7721 & Liver cancer & $32.3 \pm 1.13$ & {$[23]$} \\
\hline 8898 & Pancreas cancer & $37.2 \pm 2.15$ & - \\
\hline SPC-A-1 & Lung cancer & $84.6 \pm 4.36$ & - \\
\hline $\mathrm{HeLa}$ & Tumor of cervix uteri & $37.7 \pm 1.64$ & - \\
\hline $95-\mathrm{D}$ & High metastatic lung carcinoma & $84.8 \pm 4.71$ & - \\
\hline GBC-SD & Gall bladder carcinoma & $81.3 \pm 2.75$ & - \\
\hline A549 & Human lung cancer & $2.3 \pm 0.44$ & {$[38]$} \\
\hline HepG2 & Human liver cancer & $8.3 \pm 0.22$ & - \\
\hline MCF-7 & Human breast cancer & $15.1 \pm 0.72$ & - \\
\hline HeLa & Tumor of cervix uteri & $11.8 \pm 0.42$ & - \\
\hline $\mathrm{HeLa} / \mathrm{Tax}$ & Taxol-resistant HeLa cells & $15.3 \pm 0.19$ & - \\
\hline
\end{tabular}

with anticancer drugs, such as 5-fluorouracil (5-FU), Taxol, and doxorubicin against drug-resistant cancer cells resulted in enhanced drug sensitivity in cancer cells. Specifically, Qian et al. [15] investigated the reversal effect of DMC against doxorubicin-resistant $\mathrm{KB}-\mathrm{A} 1$ cells. In the presence of $\mathrm{DMC}$, the $\mathrm{IC}_{50}$ value of doxorubicin against KB-A1 cells dropped from $13.9 \pm 0.7$ to $3.6 \pm 0.7 \mu \mathrm{g} / \mathrm{mL}$. In the xenograft model, DMC (20 and $40 \mathrm{mg} / \mathrm{kg}$ ) potentiated the anticancer effects of doxorubicin, which was evidenced by 47.0 and $70.0 \%$ reduction of the tumor weight, respectively. The underlying mechanism was through the attenuation of MDR1 gene expression and the reduction of intracellular P-glycoprotein [15].

Cotreatment of DMC ( 4 and $8 \mu \mathrm{M}$ ) enhanced the chemosensitivity of BEL-7402/5-FU cells to 5 -FU by 3.68 and 4.92 times, respectively, while the figures for doxorubicin were 1.71 - and 2.35-fold. Flow cytometry also showed the increased apoptotic cell population when using low-dose DMC with 5-FU, compared to DMC or 5FU sole treatment [17]. A follow-up study from the same group reported the reversal effects of DMC in drug-resistant cancer cells in the human hepatocellular tumor xenograft model. A combination of low-dose DMC and 5FU significantly inhibited the growth of BEL-7402/5-FU cell xenografts $(55.6 \%$ reduction of tumor weight), compared to the inhibition rate of $22.2 \%$ and $16.7 \%$ when using 5-FU and DMC alone, respectively. In addition, the cotreatment of DMC (20 and $40 \mathrm{mg} / \mathrm{kg}$ ) also increased the accumulation of 5-FU inside tumor tissue and significantly elevated the activity of caspase-3, which plays a central role in the execution phase of cell apoptosis [16]. The underlying mechanism of DMC against the multidrug-resistant BEL-7402/5-FU hepatocellular carcinoma cells was determined to be through the mitochondriadependent apoptotic pathway and increasing the generation of ROS inside the cells. Moreover, DMC was found to block cell cycle progression at the G1 phase by downregulating the levels of related proteins, including p-GSK3 $\beta$, cyclin D1, and CDK4 [42].
To develop new anticancer agents from the DMC backbone, Wang et al. [35] synthesized a series of watersoluble DMC analogues with ionizable tertiary amine groups. These synthetic compounds were then tested alone or in a combination with Taxol. Consequently, all DMC synthetic analogues showed strong antiproliferative activities on different cancer cell lines $\left(\mathrm{IC}_{50}\right.$ values from $1.3 \pm 0.16$ to $24.7 \pm 3.94 \mu \mathrm{M}$ ), and they also displayed synergistic effects with Taxol against a multidrug-resistant cancer cell line (Hela/Tax). The most promising synergistic effects were quantified by the combination index $(\mathrm{CI}<0.15)$ and dosereduction index (DRI > 15) [38].

To summarize, the cotreatment of DMC with other wellknown anticancer drugs, such as 5-FU, doxorubicin, or Taxol, was shown to enhance the activities of the drugs, increase the accumulation of drugs in tumor tissues, and also even have synergistic effects with drugs when treated in resistant cancer cells. Further studies, especially in animal models, should be done to clarify the application of DMC in cancer treatment.

6.1.3. Chemopreventive Effects. Treatment of aqueous extract of $S$. nervosum fruit $(1000 \mathrm{mg} / \mathrm{kg})$ significantly reduced the number and size of glutathione-S-transferase placental form (GST-P)-positive foci induced by diethylnitrosamine (a rodent genotoxic compound) and phenobarbital (hepatocarcinogenic promoter), which is an important indicator for early stages of rat liver carcinogenesis. Moreover, the extract also increased remarkably the enzymatic activities of hepatic glutathione peroxidase and catalase, in comparison with the carcinogen-treated group; however, the extract did not affect the activities of glutathione reductase and heme oxygenase in rat liver. The study also suggested that the chemopreventive effects of $S$. nervosum might be due to anthocyanin constituents, which are antioxidant enhancers [18].

In another study, Inboot et al. [43] set up a Salmonella mutation assay to evaluate the antigenotoxic effects of 
S. nervosum seed extract. The results showed that the seed methanol extract was capable of inhibiting aflatoxin B1, MeIQ (2-amino-3,4 dimethylimidazo [4,5-f] quinolone)-induced mutagenesis dose-dependently, which indicated that the mode of action of $S$. nervosum seed extract might be through inhibitory effects on carcinogen-bioactivated enzymes rather than direct action on mutagens [43].

Studies on preventive effects of $S$. nervosum against carcinogens are still in the early stage, which still requires more works to draw any conclusion for the preventive benefits of the plant against cancer.

6.1.4. Underlying Mechanism of Anticancer Activities of $D M C$. The molecular mechanisms of antitumor effects of DMC (38) on different models were also investigated. In an in vivo study on a solid human tumor xenograft (SMMC7721) mouse model, DMC with a dose of $150 \mathrm{mg} / \mathrm{kg}$ was shown to significantly reduce the average tumor weight in 50 days (DMC group: $0.59 \pm 0.12 \mathrm{~g}$; control: $1.42 \pm 0.11 \mathrm{~g}$ ). The study also identified that the lethal dose of DMC was $3800 \mathrm{mg} / \mathrm{kg}$, which can be considered only slightly toxic [19]. The cytotoxic potential of DMC on human hepatoma cells (SMMC-7721) was determined via inhibiting intracellular ROS level and inducing the loss of mitochondrial membrane potential, increasing caspase- 3 and caspase- 9 activities, and downregulating the expression of $\mathrm{Bcl}-2$ protein. Interestingly, DMC shows almost no toxicity against human normal liver (L-02) and human normal fetal lung fibroblast (HFL-1) cells $[44,45]$. Other studies of anticancer effects of DMC on different cancer cell lines (K562 (leukemia cells) or PANC-1 (pancreatic cancer cells)) also indicated that the chalcone could lower Bcl-2/Bax ratio by decreasing the expression of Bcl-2 gene and activating caspase- 3 and caspase-9 $[39,46]$.

The past study results indicated that the DMC exhibited anticancer activities via multiple mechanisms of action, including genetic expression of apoptotic proteins (Bcl-2 and Bax), enhancing caspase- 3 and caspase- 9 activities, or ROS scavenging. Further works should be done to understand the biological mechanism of DMC in both cellular and animal setups.

6.2. Antidiabetic and Antiobesity Activities. There have been a number of studies on antidiabetic and antiobesity effects of S. nervosum extracts and the major compound (DMC, 38). The extracts of $S$. nervosum were shown to inhibit the activities of various digestive enzymes in vitro, including $\alpha$-glucosidase, maltase, sucrase [20], lipase, and $\alpha$-amylase [31]. It was also found out that the inhibitory effects of $S$. nervosum were relevant to total polyphenol content, particularly DMC [31]. In vivo, S. nervosum aqueous extract $(2 \mathrm{~g} / \mathrm{kg})$ also reduced postprandial glucose level of STZinduced diabetic rats after oral loading of $2 \mathrm{~g} / \mathrm{kg}$ of maltose, which was comparable to that of acarbose $(25 \mathrm{mg} / \mathrm{kg})$. The extract $(500 \mathrm{mg} / \mathrm{kg})$ was also shown to reduce blood sugar levels in fasting rats with maximal reduction after 6 hours. The authors also studied the long-term hypoglycemic effects of $S$. nervosum by giving the extract $(500 \mathrm{mg} / \mathrm{kg})$ orally to diabetic rats in 8 weeks. As a result, the $S$. nervosum extract remarkably reduced the blood glucose level and urine volume, and no sign of toxicity was observed during the study [20]. Another study performed by the same group also indicated that the aqueous extract of $S$. nervosum $(500 \mathrm{mg} /$ $\mathrm{kg}$ ) showed protective activities on $\beta$-cells of pancreatic islets in the STZ-induced diabetic rat model after 9 weeks of treatment. Histopathological results showed that there were less severe degenerative and necrotic changes in the pancreatic islets and immunohistochemical staining displayed the large area of strong insulin antigen reactivity in $\beta$-cells in the islets of Langerhans in the S. nervosum-treated group [21].

$2^{\prime}, 4^{\prime}$-dihydroxy- $6^{\prime}$-methoxy- $3^{\prime}, 5^{\prime}$-dimethylchalcone, or DMC (38), the major compound of S. nervosum flower buds, has also become a compound of interest for its potent antidiabetic and antiobesity activities via multiple mechanisms of action. DMC exhibited strong noncompetitive inhibitory effects on pancreatic $\alpha$-amylase ( IC $_{50} 43 \mu \mathrm{M}$ ) but literally ineffective against intestinal $\alpha$-glucosidase ( $\sim 20 \%$ inhibition at $200 \mu \mathrm{M})$. In addition, DMC was also capable of inhibiting glucose transporter 2 (GLUT 2; 54\% inhibition at $150 \mu \mathrm{M}$ ), which subsequently blocked the reabsorption of glucose in the kidney and therefore indirectly lowered the glycemic level. The authors also tested the protective effects of DMC against $\mathrm{H}_{2} \mathrm{O}_{2}$-induced insulin reduced secretion in MIN6 cells. As a result, the cellular viability of MIN6 cells with DMC pretreatment showed no significant changes when compared with control [47]. In another study, Hu et al. [48] studied the insulinotropic effects of DMC on glucotoxicity in RIN-5F $\beta$-cells. As a result, DMC cotreatment could stimulate insulin secretion from $\beta$-cells dose-dependently without affecting the physiological insulin secretion. The underlying mechanism was determined through the upregulation of the GLP-1 receptor and the activation of PDX-1, PRE-INS, and GLUT2-GCK signaling pathway. Besides that, DMC also reduced NO production and MCP-1 expression, which indicated the protective effects of DMC against cellular damage and oxidative stress in pancreatic islets [49]. DMC $(10 \mu \mathrm{M})$ also increased glucose uptake in differentiated adipocytes (3T3-L1). Noticeably, at high concentration (10 and $20 \mu \mathrm{M}$ ), DMC remarkably suppressed the lipid accumulation in 3T3-L1 cells while at low concentration $(2.5 \mu \mathrm{M})$, DMC stimulated the lipid storage in the same experimental cell line. The authors hypothesized that DMC upregulated the expression PPAR- $\gamma$ at a high dose and suppressed at low-dose [48]. Luo and $\mathrm{Lu}$ [50] also studied the protective effects of DMC on $\mathrm{H}_{2} \mathrm{O}_{2}$-induced cell damage in MIN6 (mouse insulinoma) cells. Pretreatment of DMC $(12.5$ and $25 \mu \mathrm{M})$ was shown to improve mitochondrial functions by reducing nucleus fragmentation, decreasing the intracellular level of ROS, and preventing the loss of mitochondrial potential [50].

Choi et al. [51] investigated the antidiabetic effects of DMC (38) in both in vitro and in vivo models. DMC was shown to increase glucose uptake and promote fatty acid oxidation (FAO) via AMPK activation in myotubes; however, the compound was found to inhibit the differentiation of adipocytes in the 3T3-L1 cellular model. In high-fat-diet obese mice, treatment of DMC could improve glucose 
tolerance, reduce average weight, and increase the oxidation of fatty acids in muscle tissues. The mechanism of action was determined via FAO stimulation, which was mediated by AMPK activation in muscle [51].

In summary, there have been a large number of pieces of evidence about the antidiabetic and antiobesity properties of $S$. nervosum extract and its major constituent (DMC) in both in vitro and in vivo experimental setups. S. nervosum extracts were shown to inhibit polysaccharide hydrolytic enzymes, reduce blood sugar level, and protect pancreatic islets in rat models. On the other hand, the major chalcone DMC was capable of stimulating insulin secretion, increasing glucose uptake in differentiated adipocytes, and protecting pancreatic islet cells from oxidative stress, cellular damage, and glucotoxicity. Furthermore, DMC was also found to reduce lipid accumulation and promote fatty acid oxidation in the mouse. Although antidiabetic and antiobesity activities are not therapeutic indications of the plant in traditional medicine, these study results strongly suggested the potential clinical application of this plant in the fight against chronic conditions, such as diabetes and obesity. Clinical studies are required to confirm the pharmacological properties in humans.

6.3. Antioxidant Activities. Since the major components of S. nervosum are flavonoids, the extract and its constituents were also examined for antioxidant activities via different bioassays. The fruit extract of $S$. nervosum was shown to protect the kidney from cadmium-induced oxidative injury in rats. The oral administration of the extract $(0.5-2.0 \mathrm{~g} / \mathrm{kg})$ clearly reduced the levels of blood urea nitrogen and plasma creatinine, which resulted in the restoration of creatinine clearance, in comparison with the cadmium alone-treated group. Histopathological examination also evidenced the protective effects of $S$. nervosum fruit extract $(1-2 \mathrm{~g} / \mathrm{kg})$ against cadmium intoxication, specifically the diminishment of severe tubular necrosis, vacuolar degeneration, and glomerular structural changes. Further molecular investigation indicated that the fruit extract of $S$. nervosum reduced the levels of nitric oxide (NO) and malondialdehyde (MDA) and restored the levels of antioxidative enzymes, such as superoxide dismutase (SOD) and catalase (CAT), and nonenzymatic antioxidants (total, free, and protein thiols) [33].

The major compound, DMC (38), was also studied for the protective effects against $\mathrm{H}_{2} \mathrm{O}_{2}$-induced injuries in endothelial cells and hepatocytes. DMC showed potent ABTS radical scavenging activity $(176.5 \pm 5.2 \mu \mathrm{mol}$ Trolox equivalents $/ 500 \mu \mathrm{mol}$ DMC), ferric reducing activity $(213.3 \pm 5.8 \mu \mathrm{mol}$ Trolox equivalents $/ 500 \mu \mathrm{mol} \mathrm{DMC})$, and hydroxyl radical scavenging activity $\left(\mathrm{IC}_{50} 243.7 \pm 6.3 \mu \mathrm{M}\right)$ in respective experiments. In the cellular assay, DMC was shown to protect human umbilical vein endothelial ECV304 cells against $\mathrm{H}_{2} \mathrm{O}_{2}$-induced cytotoxicity through mechanisms of reducing intra- and extracellular ROS levels [52]. Pretreatment of DMC also demonstrated protective effects against $\mathrm{H}_{2} \mathrm{O}_{2}$-induced hepatotoxicity. In specific, DMC reduced the levels of $\mathrm{NO}$ and lactate dehydrogenase
(LDH), inhibited the accumulation of MDA, and restored the reduced glutathione (GSH) level inside the liver cells [49].

As for other constituents, a study conducted by Min et al. [13] indicated that compounds 36 and 52 exhibited potent DPPH (1,1-diphenyl-2-picrylhydrazyl) radical scavenging activity with $\mathrm{IC}_{50}$ values of 22.8 and $27.1 \mu \mathrm{M}$, respectively, which were comparable to that of positive control, $\alpha$-tocopherol $(20.1 \mu \mathrm{M})$ [13]. Other flavonoids (35 and 54) also showed moderate antioxidant effects in different bioassays, including $\mathrm{DPPH}$ radical scavenging assay $\left(\mathrm{IC}_{50}\right.$ $50.2 \pm 2.8 \mu \mathrm{M}$ and $75.8 \pm 2.5 \mu \mathrm{M}$, respectively), superoxide radical scavenging assay $\left(\mathrm{IC}_{50} \quad 56.3 \pm 2.3 \mu \mathrm{M}\right.$ and $317.5 \pm 2.9 \mu \mathrm{M}$, respectively), and lipid peroxidation $(64.3 \pm 2.5 \%$ and $60.3 \pm 2.3 \%$ inhibition at $500 \mu \mathrm{M}$, respectively) [36].

With the very high content of phenolic compounds, S. nervosum extract has shown potent antioxidant effects in various bioassays. The fruit extract showed its renal protection from cadmium intoxication in the rat model while DMC was found to protect endothelial cells and hepatocytes from $\mathrm{H}_{2} \mathrm{O}_{2}$-induced injuries. Since antioxidant activity is related to a wide range of pharmacological activities, such as anticancer, anti-inflammatory, hepatoprotective, and neuroprotective activities, the potent antioxidant activity may provide research ideas and directions for exploring other pharmacological effects of the plant and its constituents.

6.4. Neuroprotective Activities. The berry extract of S. nervosum was studied for its neuroprotective activities in the Caenorhabditis elegans model. As a result, the fruit extract was shown to prolong the average and maximum lifespan (test group: 27-30 days; control group: up to 22 days), as well as healthspan of the nematode by reducing the level of lipofuscin, which is an indicator of aging, and modulating the expression of healthspan-related genes. The detailed mechanism was determined to be DAF-16-interdependent by the upregulation of the family of transcription factors and the ability to extend the lifespan of DAF-16 mutant species. Furthermore, the extract was also capable of reducing the ROS level inside the nematode, which includes the involvement of skn-1 and sir-2.1 gene expression [53]. The fruit extract was also shown to inhibit glutamate-induced apoptosis by suppressing the endoplasmic reticulum stress, reduce the intracellular ROS level, and increase the expression of endogenous antioxidant enzymes, such as superoxide dismutase (SOD), catalase (CAT), and glutathione peroxidase (GPx), which was tested on mouse hippocampal neuronal cells (HT22) [34]. It can be seen that despite the limited number of publications on the neuroprotective effects of S. nervosum fruit extract, the initial data on the C. elegans model were shown very promising. Hence, the research area of the neuroprotective potential of $S$. nervosum should receive more attention from the scientific community. Extensive bioguided phytochemical studies should be carried out to discover the correlation of bioactive compounds and their respective mode of action. 
6.5. Antiviral Activities. The antiviral properties of $S$. nervosum and its phenolic components were also investigated. Oh's group conducted bioactivity-directed isolation to identify the responsible compounds from S. nervosum flower buds by $\mathrm{H} 1 \mathrm{~N} 1$ neuraminidase inhibition assay. The most active compounds in H1N1 neuraminidase (wild type) assay were identified as C-methylated flavonoids with $\mathrm{IC}_{50}$ values ranging from $8.15 \pm 1.05$ to $93.77 \pm 5.35 \mu \mathrm{M}$. Interestingly, when tested on H274Y-mutant type (oseltamivirresistant type), these compounds exhibited 2.46-7.00 times more potent, which was opposite to the oseltamivir case. Kinetic studies also revealed the underlying mechanism of these compounds as noncompetitive inhibitory mode [8]. The constituents from $S$. nervosum leaves were also found to inhibit the enzymatic activity of influenza neuraminidase. Noticeably, besides the C-methylated flavonoids, glycosides (45 and 47) were also active against neuraminidase [11]. A phloroglucinol-focused fractionation with the direction of QTOF/MS on S. nervosum leaves led to the isolation of four novel phloroglucinol compounds (82-85). Among them, cleistoperlone A (82) exhibited the strongest inhibitory effects on HSV-1 (herpes simplex virus type-1) in a cytopathic effect (CPE) reduction assay with the $\mathrm{IC}_{50}$ value of $7.50 \pm 1.25 \mu \mathrm{M}$ and $\mathrm{SI}>13.33[10]$.

One of the most common uses of S. nervosum in traditional Vietnamese and Chinese medicine is treating influenza. Current studies revealed that the C-methylated flavonoids were responsible compounds for anti-influenza activity of the extract. These findings may support the traditional claim of $S$. nervosum as an anti-influenza herb. However, published studies only reported the pharmacological results in enzymatic and cellular bioassays. Therefore, further in vivo studies should be conducted to confirm the anti-influenza effects of the plant in animal models, thereby laying the foundation for clinical trials.

6.6. Anti-Inflammatory Activities. The major component, DMC (38), was studied for its anti-inflammatory activities in multiple pathways. DMC was found to downregulate the expression of inflammatory mediators, including TNF- $\alpha$ (tumor necrosis factor- $\alpha$ ), IL-1 $\beta$ (interleukine-1 $\beta$ ), IL-6 (interleukine-6), and HMGB1 (High mobility group box 1), and reduce their production time- and dose-dependently in LPS-induced RAW264.7 macrophages. The detailed mechanistic study indicated that DMC suppressed the secretion of HMGB1, blocked the translocation of nucleocytoplasmic HMGB1, and interfered with the PI3K-PDK1-PKC $\alpha$ signaling pathway [54]. DMC also exhibited similar anti-inflammatory activities in LPS-stimulated rat Kupffer cells [55]. S. nervosum extract and DMC were also shown to attenuate LPS-stimulated inflammatory responses by inhibiting the production of inflammatory and proinflammatory mediators and activating the Nrf2/HO- 1 pathway in macrophages. In vivo experiments showed that the oral administration of S. nervosum extract (100-200 mg/ $\mathrm{kg}$ ) reduced the mortality rate of experimental septic mice (60-80\% survival rate), compared to $80 \%$ mortality rate in the control group. Histopathological examination also revealed the extract $(200 \mathrm{mg} / \mathrm{kg})$ ameliorated the swelling of the alveolar wall, alveolar congestion, and hepatic tissue damage in the experimental mice [12].

Previous studies have indicated the potential anti-inflammatory effects of S. nervosum extracts and DMC, which verified the traditional uses of the plant in folklore medicine, for example, skin diseases, pimples, and breast inflammation. S. nervosum extracts and its major flavonoid (DMC) were found to downregulate the expression of inflammatory and proinflammatory mediators. However, there have been limited animal studies on anti-inflammatory activities of the plant and isolated bioactive compounds.

6.7. Other Bioactivities. The aqueous extract of $S$. nervosum was found to improve the contraction of isolated rat heart, specifically increasing the contractility and reducing the contractile frequency pattern. A follow-up molecular experiment demonstrated that $S$. nervosum water extract inhibited $\mathrm{Na}^{+} / \mathrm{K}^{+}$-ATPase pump activities in a dose-dependent manner, which can explain the observed positive inotropic effects of the extract. The negative chronotropic effects were determined to relate with $\mathrm{Ca}^{2+}$-dependent ATPases, which eventually decreases the heart rate. The study suggested that the underlying mechanism of cardiotonic action of $S$. nervosum is more complex than that of ouabain, a well-known cardiac glycoside [29].

The antimicrobial activities of $S$. nervosum were also investigated. The methanol leave extract was tested against six strains of Gram-positive bacteria, two strains of Gramnegative bacteria, and one fungal species. Consequently, the extract $(0.1 \mathrm{mg} / \mathrm{mL})$ exhibited inhibitory activities against seven out of nine experimental bacterial species. Furthermore, the extract also showed anticaries activity against Streptococcus mutans (dental plaque organism) by inhibiting acid production and biofilm formation in a dose-dependent manner [56].

Tran et al. [24] published a study on antiosteoclastogenic activities of the ethanol extract of $S$. nervosum flower bud and its constituents. The extract was shown to suppress RANKL (receptor activator of nuclear factor-kappa-B ligand)-induced osteoclast formation via inhibiting the activation of c-Fos (a proto-oncogene) and NFATc1 (nuclear factor of activated $\mathrm{T}$ cell cytoplasmic 1). The authors also conducted bioactivity-directed isolation to identify the active compounds for antiosteoclastogenic effects from S. nervosum extract. As a result, maslinic acid (27) and its two coumaroyl derivatives ( 28 and $\mathbf{2 9}$ ) were the responsible compounds [24].

The major chalcone-type compound from S. nervosum, DMC (38), was also studied for its cellular protective effects against $\mathrm{H}_{2} \mathrm{O}_{2}$-mediated cellular damage in pheochromocytoma cells (PC12). DMC increased the levels of glutathione and superoxide dismutase, leading to the reduction of endogenous ROS, which eventually protected cells from oxidative damage. Furthermore, DMC was also found to preserve mitochondrial membrane potential, which is an important indicator of cellular apoptotic activation, and 
decrease the caspase- 3 activity in $\mathrm{H}_{2} \mathrm{O}_{2}$-treated PC12 cells [57].

Besides well-studied pharmacological effects like anticancer, antidiabetic, antioxidant, and anti-inflammatory activities, $S$. nervosum extract and its chemical compositions were also investigated in other bioassays, such as cardiotonic, antibacterial, anticaries, cellular protective, and antiosteoclastogenic activities. However, these studies are currently in the early stage, which requires further works on the mechanism of action and animal models to support future clinical application.

\section{Conclusion and Perspective}

In a nearly 20-year period, there have been a large number of studies conducted on $S$. nervosum, mainly in leaves and flower buds part. Phytochemical investigations have revealed that triterpenoids, flavonoids, and phloroglucinols are the main components of $S$. nervosum. Among them, C-methylated flavonoids stand out as bioactive compounds which are responsible for pharmacological activities of the plant, especially for the case of $2^{\prime}, 4^{\prime}$-dihydroxy- $6^{\prime}$-methoxy$3^{\prime}, 5^{\prime}$-dimethylchalcone (DMC), while other major compound groups like triterpenoid and phloroglucinol were not paid enough attention in terms of pharmacological properties. Analytical studies reported the inconsistent content of DMC in S. nervosum flower buds, which suggested that DMC content might depend on plant varieties, location, and most importantly harvest time because the flavonoid content in flower buds can be changed in different flowering stages. Therefore, it is necessary to propose the standardization of varieties, geographical regions, and time of harvest. Such efforts will lay a practical basis for the development, modernization, and utilization of this plant in clinical practice.

S. nervosum extract and its major compound, DMC, were also investigated for pharmacological properties in various bioassays. The most noticeable bioactivities that should be mentioned are anticancer, antiviral, and antidiabetic activities. DMC showed potent cytotoxicity against various cancer cell lines via different mechanisms of action. In addition, DMC was found to reverse the drug-resistant abilities of cancer cells and significantly improve the anticancer effects of well-known drugs, such as 5-FU, doxorubicin, and Taxol. Some research groups successfully exploited the simplicity of the C-methylated chalcone backbone to synthesize analogues for significantly improved anticancer activities. This approach can be considered a promising direction for novel anticancer agent discovery.

Antiviral activities of $S$. nervosum also showed very promising results in in vitro setups, especially against influenza viruses ( $\mathrm{H} 1 \mathrm{~N} 1$ and $\mathrm{H} 9 \mathrm{~N} 2)$, which supported the traditional use of the plant against influenza. However, further animal and clinical studies are required before any clinical recommendation is made. Besides that, further pharmacological studies should focus on bioactivities of triterpenoids, phloroglucinols, and other flavonoid derivatives, which are also the major constituents of $S$. nervosum with undiscovered bioactive potentials.
As for the antidiabetic effect, S. nervosum and DMC were found to exhibit very promising activities in both in vitro and in vivo experiments. Although antidiabetes is not a curative indication of $S$. nervosum in traditional medicine, the pharmacological activity deserves more attention to identify the optimal dose and long-term effects in both animal and clinical studies. Further research should be performed to shed light on the clinical application of S. nervosum in the treatment of diabetes.

Although a large number of pharmacological studies were conducted, comprehensive studies to evaluate toxicity and safety of the plant are still absent. Long-term and shortterm toxicity assessment should be carried out to identify potential risks and adverse effects of the plant and its constituents. Pharmacokinetic and pharmacodynamic studies are also very important to evaluate absorption, distribution, metabolism, and excretion of active substances, thereby providing dose estimation for humans.

In summary, the review provides an overview of ethnopharmacology and the current status of research on S. nervosum, including phytochemical, analytical, and pharmacological studies, which revealed the high potential of this medicinal plant for treatment of various diseases and conditions.
Abbreviations
5-FU: Fluorouracil
DMC: $\quad 2^{\prime}, 4^{\prime}$-Dihydroxy- $6^{\prime}$-methoxy- $3^{\prime}, 5^{\prime}-$ dimethylchalcone
MS: $\quad$ Mass spectrometry
NMR: Nuclear magnetic resonance
RANKL: Receptor activator of nuclear factor-kappa-B ligand
ROS: $\quad$ Reactive oxygen species
STZ: Streptozotocin.

\section{Conflicts of Interest}

The authors declare no conflicts of interest in this article.

\section{Acknowledgments}

This research was funded by PHENIKAA University under grant no. 01.2020.04.

\section{References}

[1] T. L. Do, Vietnamese Medicinal Plants and Herbs, Medical Publishing House, Hanoi, Vietnam, 12th edition, 2004.

[2] Nanjing China Medical University, Dictionary of Chinese Medicine, Shanghai Science Publishing House, Shanghai, China, 2005.

[3] National Institute of Medicinal Materials, Medicinal Plants and Animals in Vietnam-Volume 2, Science and Technology Publishing House, Shanghai, China, 2006.

[4] Vietnam Pharmacopoeia Council, Vietnam Pharmacopoeia V, Medical Publishing House, Hanoi, Vietnam, 2017.

[5] Editorial Committee of Guangdong Chinese Medicine Journal, Guangdong Chinese Medicine Journal, Guangdong Science and Technology Press, Guangdong, China, 1994. 
[6] B. Su, Lingnan Herbal Medicine Record, Guangdong Science and Technology Press, Guangdong, China, 2016.

[7] C. Wang, P. Wu, S. Tian et al., "Bioactive pentacyclic triterpenoids from the leaves of Cleistocalyx operculatus," Journal of Natural Products, vol. 79, no. 11, pp. 2912-2923, 2016.

[8] T.-T. Dao, B.-T. Tung, P.-H. Nguyen et al., "C-methylated flavonoids from Cleistocalyx operculatus and their inhibitory effects on novel influenza A (H1N1) neuraminidase," Journal of Natural Products, vol. 73, no. 10, pp. 1636-1642, 2010.

[9] J.-G. Song, J.-C. Su, Q.-Y. Song et al., "Cleistocaltones A and $\mathrm{B}$, antiviral phloroglucinol-terpenoid adducts from Cleistocalyx operculatus," Organic Letters, vol. 21, no. 23, pp. 9579-9583, 2019.

[10] J.-C. Su, S. Wang, W. Cheng et al., "Phloroglucinol derivatives with unusual skeletons from Cleistocalyx operculatus and their in vitro antiviral activity," The Journal of Organic Chemistry, vol. 83, no. 15, pp. 8522-8532, 2018.

[11] T. K. Q. Ha, T. T. Dao, N. H. Nguyen et al., "Antiviral phenolics from the leaves of Cleistocalyx operculatus," Fitoterapia, vol. 110, pp. 135-141, 2016.

[12] P.-L. Tran, O. Kim, H. N. K. Tran et al., "Protective effects of extract of Cleistocalyx operculatus flower buds and its isolated major constituent against LPS-induced endotoxic shock by activating the Nrf2/HO-1 pathway," Food and Chemical Toxicology, vol. 129, pp. 125-137, 2019.

[13] B. S. Min, C. V. Thu, N. T. Dat, N. H. Dang, H. S. Jang, and T. M. Hung, "Antioxidative flavonoids from Cleistocalyx operculatus buds," Chemical \& Pharmaceutical Bulletin, vol. 56, no. 12, pp. 1725-1728, 2008.

[14] Y. Lu, Y. Y. Zhang, Y. C. Hu, and Y. H. Lu, "Protective effects of $\quad 2^{\prime}, 4^{\prime}$-dihydroxy-6'-methoxy- $3^{\prime}, 5^{\prime}$-dimethylchalcone against hydrogen peroxide-induced oxidative stress in hepatic L02 cell," Archives of Pharmacal Research, vol. 37, no. 9, pp. 1211-1218, 2014.

[15] F. Qian, C. L. Ye, D. Z. Wei, Y. H. Lu, and S. L. Yang, "In vitro and in vivo reversal of cancer cell multidrug resistance by $2^{\prime}, 4^{\prime}$-dihydroxy- $6^{\prime}$-methoxy-3', $5^{\prime}$-dimethylchalcone," Journal of Chemotherapy, vol. 17, no. 3, pp. 309-314, 2005.

[16] H. Y. Huang, J. L. Niu, and Y. H. Lu, "Multidrug resistance reversal effect of DMC derived from buds of Cleistocalyx operculatus in human hepatocellular tumor xenograft model," Journal of the Science of Food and Agriculture, vol. 92, no. 1, pp. 135-140, 2012.

[17] H. Y. Huang, J. L. Niu, L. M. Zhao, and Y. H. Lu, "Reversal effect of $2^{\prime}, 4^{\prime}$-dihydroxy- $6^{\prime}$-methoxy- $3^{\prime}, 5^{\prime}$-dimethylchalcone on multi-drug resistance in resistant human hepatocellular carcinoma cell line BEL-7402/5-FU," Phytomedicine, vol. 18, no. 12, pp. 1086-1092, 2011.

[18] S. Taya, C. Punvittayagul, W. Inboot, S. Fukushima, and R. Wongpoomchai, "Cleistocalyx nervosum extract ameliorates chemical-induced oxidative stress in early stages of rat hepatocarcinogenesis," Asian Pacific Journal of Cancer Prevention, vol. 15, no. 6, pp. 2825-2830, 2014.

[19] C. L. Ye, J. W. Liu, D. Z. Wei, Y. H. Lu, and F. Qian, "In vivo antitumor activity by $2^{\prime}, 4^{\prime}$-dihydroxy- $6^{\prime}$-methoxy- $3^{\prime}, 5^{\prime}$ dimethylchalcone in a solid human carcinoma xenograft model," Cancer Chemotherapy and Pharmacology, vol. 55, no. 5, pp. 447-452, 2005.

[20] M. Truong Tuyet and C. Nguyen Van, "Anti-hyperglycemic activity of an aqueous extract from flower buds of Cleistocalyx operculatus (Roxb.) Merr and Perry," Bioscience, Biotechnology, and Biochemistry, vol. 71, no. 1, pp. 69-76, 2007.
[21] T. T. Mai, K. Yamaguchi, M. Yamanaka, N. T. Lam, Y. Otsuka, and N. V. Chuyen, "Protective and anticataract effects of the aqueous extract of Cleistocalyx operculatus flower buds on beta-cells of streptozotocin-diabetic rats," Journal of Agricultural and Food Chemistry, vol. 58, no. 7, pp. 4162-4168, 2010.

[22] P. M. Giang, V. T. Phuong, and T. T. Chinh, "A new taraxastane-type triterpenoid from Cleistocalyx operculatus," Natural Product Communications, vol. 11, no. 1, pp. 29-30, 2016.

[23] C. L. Ye, J. W. Liu, D. Z. Wei, Y. H. Lu, and F. Qian, "In vitro anti-tumor activity of $2^{\prime}, 4^{\prime}$-dihydroxy- $6^{\prime}$-methoxy- $3^{\prime}, 5^{\prime}$ dimethylchalcone against six established human cancer cell lines," Pharmacological Research, vol. 50, no. 5, pp. 505-510, 2004.

[24] P. T. Tran, T. Q.-M. Ngo, S. Lee et al., "Identification of antiosteoclastogenic compounds from Cleistocalyx operculatus flower buds and their effects on RANKL-induced osteoclastogenesis," Journal of Functional Foods, vol. 60, p. 103388, 2019.

[25] A. Chailungka, T. Junpirom, W. Pompimon, N. Nuntasaen, and P. Meepowpan, "Two flavonoids first isolated from the seed of Syzygium nervosum and preliminary study of their anticancer and anti-HIV-1 reverse transcriptase activities," Maejo International Journal of Science and Technology, vol. 11, no. 1, pp. 58-67, 2017.

[26] B. S. Min, T. D. Cuong, J.-S. Lee, M. H. Woo, and T. M. Hung, "Flavonoids from Cleistocalyx operculatus buds and their cytotoxic activity," Bulletin of the Korean Chemical Society, vol. 31, no. 8, pp. 2392-2394, 2010.

[27] B. S. Min, T. D. Cuong, J. S. Lee, B. S. Shin, M. H. Woo, and T. M. Hung, "Cholinesterase inhibitors from Cleistocalyx operculatus buds," Archives of Pharmacal Research, vol. 33, no. 10, pp. 1665-1670, 2010.

[28] C. L. Ye, Y. H. Lu, X. D. Li, D. Z. Wei, and C. S. Whitehead, "HPLC analysis of a bioactive chalcone and triterpene in the buds of Cleistocalyx operculatus," South African Journal of Botany, vol. 71, no. 3, pp. 312-315, 2005.

[29] A. Y. Woo, M. M. Waye, H. S. Kwan, M. C. Chan, C. F. Chau, and C. H. Cheng, "Inhibition of ATPases by Cleistocalyx operculatus. A possible mechanism for the cardiotonic actions of the herb," Vascular Pharmacology, vol. 38, no. 3, pp. 163-168, 2002.

[30] M. Truong Tuyet, N. Fumie, and V. C. Nguyen, "Antioxidant activities and hypolipidemic effects of an aqueous extract from flower buds of Cleistocalyx operculatus (Roxb.) Merr. and Perry," Journal of Food Biochemistry, vol. 33, no. 6, pp. 790-807, 2009.

[31] L. Zhang and Y. Lu, "Inhibitory activities of extracts from Cleistocalyx operculatus flower buds on pancreatic lipase and $\alpha$-amylase," European Food Research and Technology, vol. 235, no. 6, pp. 1133-1139, 2012.

[32] J. Manosroi, C. Chankhampan, K. Kumguan, W. Manosroi, and A. Manosroi, "In vitro anti-aging activities of extracts from leaves of Ma Kiang (Cleistocalyx nervosum var. paniala)," Pharmaceutical Biology, vol. 53, no. 6, pp. 862-869, 2015.

[33] W. Poontawee, S. Natakankitkul, and O. Wongmekiat, "Protective effect of Cleistocalyx nervosum var. paniala fruit extract against oxidative renal damage caused by cadmium," Molecules, vol. 21, no. 2, p. 133, 2016.

[34] M. Sukprasansap, P. Chanvorachote, and T. Tencomnao, "Cleistocalyx nervosum var. paniala berry fruit protects neurotoxicity against endoplasmic reticulum stress-induced 
apoptosis," Food and Chemical Toxicology, vol. 103, pp. 279-288, 2017.

[35] J. Wang, L.-y. Yao, and Y.-h. Lu, "Ceriporia lacerata DMC1106, a new endophytic fungus: isolation, identification, and optimal medium for $2^{\prime}, 4^{\prime}$-dihydroxy- $6^{\prime}$-methoxy- $3^{\prime}, 5^{\prime}$ dimethylchalcone production," Biotechnology and Bioprocess Engineering, vol. 18, no. 4, pp. 669-678, 2013.

[36] C. L. Ye, Y. Liu, and D. Z. Wei, "Antioxidant and anticancer activity of $3^{\prime}$-formyl- $4^{\prime}, 6^{\prime}$-dihydroxy-2'-methoxy-5'-methylchalcone and (2S)-8-formyl-5-hydroxy-7-methoxy-6-methylflavanone," The Journal of Pharmacy and Pharmacology, vol. 59, no. 4, pp. 553-559, 2007.

[37] X. Zhuo, L. En-Zhen, L. Hai et al., "Concise synthesis and cellular evaluation of $3^{\prime}$-formyl- $4^{\prime}, 6^{\prime}$-dihydroxy- $2^{\prime}$-methoxy$5^{\prime}$-methylchalcone (FMC) and its analogues," Synthetic Communications, vol. 44, no. 21, pp. 3139-3147, 2014.

[38] C. Wang, P. Wu, X.-L. Shen, X.-Y. Wei, and Z.-H. Jiang, "Synthesis, cytotoxic activity and drug combination study of tertiary amine derivatives of $2^{\prime}, 4^{\prime}$-dihydroxyl- $6^{\prime}$-methoxyl3',5'-dimethylchalcone," RSC Advances, vol. 7, no. 76, pp. 48031-48038, 2017.

[39] H. N. Tuan, B. H. Minh, P. T. Tran et al., "The effects of $2^{\prime}, 4^{\prime}-$ dihydroxy- $6^{\prime}$-methoxy- $3^{\prime}, 5^{\prime}$ - dimethylchalcone from Cleistocalyx operculatus buds on human pancreatic cancer cell lines," Molecules, vol. 24, no. 14, pp. 25-38, 2019.

[40] J.-F. Shi, P. Wu, Z.-H. Jiang, and X.-Y. Wei, "Synthesis and tumor cell growth inhibitory activity of biotinylated annonaceous acetogenins," European Journal of Medicinal Chemistry, vol. 71, pp. 219-228, 2014.

[41] A. Ben Trivedi, N. Kitabatake, and E. Doi, "Toxicity of dimethyl sulfoxide as a solvent in bioassay system with HeLa cells evaluated colorimetrically with 3-(4,5-dimethylthiazol-2yl)-2,5-diphenyl-tetrazolium bromide," Agricltural Biological Chemistry, vol. 54, no. 11, pp. 2961-2966, 1990.

[42] X. Ji, X. Wei, J. Qian et al., " 2 ' $4^{\prime}$-Dihydroxy-6'-methoxy$3^{\prime}, 5^{\prime}$-dimethylchalcone induced apoptosis and G1 cell cycle arrest through PI3K/AKT pathway in BEL-7402/5-FU cells," Food and Chemical Toxicology, vol. 131, pp. 110-533, 2019.

[43] W. Inboot, S. Taya, A. Chailungka, P. Meepowpan, and R. Wongpoomchai, "Genotoxicity and antigenotoxicity of the methanol extract of Cleistocalyx nervosum var. paniala seed using a Salmonella mutation assay and rat liver micronucleus tests," Molecular \& Cellular Toxicology, vol. 8, no. 1, pp. 19-24, 2012.

[44] C. L. Ye and Y. F. Lai, “ 2 ', $4^{\prime}$-Dihydroxy- $6^{\prime}$-methoxy- $3^{\prime}, 5^{\prime}$ dimethylchalcone, from buds of Cleistocalyx operculatus, induces apoptosis in human hepatoma SMMC-7721 cells through a reactive oxygen species-dependent mechanism," Cytotechnology, vol. 68, no. 2, pp. 331-341, 2016.

[45] C.-L. Ye, X.-G. Liu, Q. Huang, and X.-L. Zhao, "Induction of apoptosis in human hepatoma SMMC-7721 cells using $2^{\prime}, 4^{\prime}$ Dihydroxy- $6^{\prime}$-methoxy- $3^{\prime}, 5^{\prime}$-dimethylchalcone, a chalcone from buds of Cleistocalyx operculatus," Food Science and Biotechnology, vol. 22, no. 5, pp. 1-7, 2013.

[46] C. L. Ye, F. Qian, D. Z. Wei, Y. H. Lu, and J. W. Liu, "Induction of apoptosis in K562 human leukemia cells by $2^{\prime}, 4^{\prime}$ dihydroxy- $6^{\prime}$-methoxy- $3^{\prime}, 5^{\prime}$-dimethylchalcone," Leukemia Research, vol. 29, no. 8, pp. 887-892, 2005.

[47] Y. C. Hu, Y. D. Luo, L. Li, M. K. Joshi, and Y. H. Lu, "In vitro investigation of $2^{\prime}, 4^{\prime}$-dihydroxy- $6^{\prime}$-methoxy- $3^{\prime}, 5^{\prime}$-dimethylchalcone for glycemic control," Journal of Agricultural and Food Chemistry, vol. 60, no. 42, pp. 10683-10688, 2012.

[48] Y. C. Hu, Z. Zhang, W. G. Shi et al., ' 2 ', $4^{\prime}$-Dihydroxy-6'methoxy- $3^{\prime}, 5^{\prime}$-dimethylchalcone promoted glucose uptake and imposed a paradoxical effect on adipocyte differentiation in 3T3-L1 cells," Journal of Agricultural and Food Chemistry, vol. 62, no. 8, pp. 1898-1904, 2014.

[49] Y. C. Hu, D. M. Hao, L. X. Zhou et al., " $2^{\prime}, 4^{\prime}$-Dihydroxy-6' methoxy-3', $5^{\prime}$-dimethylchalcone protects the impaired insulin secretion induced by glucotoxicity in pancreatic $\beta$-cells," Journal of Agricultural and Food Chemistry, vol. 62, no. 7, pp. 1602-1608, 2014.

[50] Y. Luo and Y. Lu, " 2 ', $4^{\prime}$-dihydroxy- $6^{\prime}$-methoxy- $3^{\prime}, 5^{\prime}$-dimethylchalcone inhibits apoptosis of MIN6 cells via improving mitochondrial function," Pharmazie, vol. 67, no. 9, pp. 798803, 2012.

[51] J. W. Choi, M. Kim, H. Song et al., "DMC (2', $4^{\prime}$-dihydroxy-6' methoxy- $3^{\prime}, 5^{\prime}$-dimethylchalcone) improves glucose tolerance as a potent AMPK activator," Metabolism, vol. 65, no. 4, pp. 533-542, 2016.

[52] C.-L. Ye, X.-G. Liu, and Q. Huang, "Antioxidant activity and protection of human umbilical vein endothelial cells from hydrogen peroxide-induced injury by DMC, a chalcone from buds of Cleistocalyx operculatus," South African Journal of Botany, vol. 86, pp. 36-40, 2013.

[53] M. I. Prasanth, J. M. Brimson, S. Chuchawankul, M. Sukprasansap, and T. Tencomnao, "Antiaging, stress resistance, and neuroprotective efficacies of Cleistocalyx nervosum var. paniala fruit extracts using Caenorhabditis elegans model," Oxidative Medicine and Cellular Longevity, vol. 2019, Article ID 7024785, 14 pages, 2019.

[54] W.-G. Yu, H. He, J.-Y. Yao, Y.-X. Zhu, and Y.-H. Lu, "Dimethyl cardamonin exhibits anti-inflammatory effects via interfering with the PI3K-PDK1-PKC $\alpha$ signaling pathway," Biomolecules \& Therapeutics, vol. 23, no. 6, pp. 549-556, 2015.

[55] W.-G. Yu, H. He, J. Qian, and Y.-H. Lu, "Dual role of $2^{\prime}, 4^{\prime}$ dihydroxy-6'-methoxy-3', $5^{\prime}$-dimethylchalcone in inhibiting high-mobility group box 1 secretion and blocking its proinflammatory activity in hepatic inflammation," Journal of Agricultural and Food Chemistry, vol. 62, no. 49, pp. 1194911956, 2016.

[56] P. T. M. Nguyen, N. Schultze, C. Boger, Z. Alresley, A. Bolhuis, and U. Lindequist, "Anticaries and antimicrobial activities of methanolic extract from leaves of Cleistocalyx operculatus L." Asian Pacific Journal of Tropical Biomedicine, vol. 7, no. 1, pp. 43-48, 2017.

[57] M. Y. Su, H. Y. Huang, L. Li, and Y. H. Lu, "Protective effects of $2^{\prime}, 4^{\prime}$-dihydroxy- $6^{\prime}$-methoxy- $3^{\prime}, 5^{\prime}$-dimethylchalcone to PC12 cells against cytotoxicity induced by hydrogen peroxide," Journal of Agricultural and Food Chemistry, vol. 59, no. 2, pp. 521-527, 2011. 